\title{
Green Economy a Design for Sustainable Development of India
}

\author{
P.S. Kamble
}

Department of Economics, Shivaji University, Kolhapur, Maharashtra, India

Corresponding author: pskamble2006@gmail.com

Received: 05 Mar., 2020

Revised: 23 Apr., 2020

Accepted: 28 May, 2020

\begin{abstract}
Industrial revolution turned India into a source of rare, raw materials for British industries as well as a market for their finished products. The British only concentrated on the use of production factors and mass production for earning profit and collecting wealth for selfish development and it has led to a depletion of certain natural resources, leaving the environment permanently damaged and injured. The environmental issues in India become more serious every day like that lack of environmental education, reducing fertility of agricultural land, declining water level on earth, mass deforestation, land degradation, excess use of fertilizers and chemical in food production and river contamination and pollution. Green economy is a design and remedy on sustainable development, sustainable environment and environmental balance. It is against this backdrop, the present research study analyses the state of green economy and its linkages with sustainable development, environmental sustainability with reference to India. The present study concludes that the depletion of natural resources in India was not over or excessive is a move towards a green economy in connection with the indicator of natural resource depletion. The state of sanitation facilities in India is not very much happy and satisfactory. Access to water shows for India it is good, but not better which reveals India has failed in providing drinking water, consequently economic transformation and green economy for sustainable development of India. The important and policy suggestions of the present study are; planned extensive and intensive efforts are very much necessary from India as well for the development of health, water supply and sanitation facilities. Government of India should be more active and dynamic in realizing their green economy. Participation and involvement of people should be obligatory and enhanced in undertaking various activities useful for attaining the green economy and there by sustainable development.
\end{abstract}

Keywords: Green Economy, Sustainable development, Environmental Sustainability, Indicators, Economic Transformation, Resource Efficiency, Progress and Well-being

The Industrial Revolution started in 1770 was characterized by a change in the manufacturing process through the use of machinery, chemical, education, skilled labour, new ideas, and other innovations. This time period was a distinct working class which worked in the factories and industries of the richer class of society, industrial owner often producing goods for relatively low pay in less than suitable conditions. The middle hub of the Industrial Revolution was Great Britain. India served to develop the Britain's market for the sale of Britain's manufactured and processed goods. However, India did not largely benefit from the Industrial Revolution in the way that Great Britain did. In reality, Indian economy was devastated by

How to cite this article: Kamble, P.S. (2020). Green Economy a Design for Sustainable Development of India. International Journal of Inclusive Development, 6(1): 45-61.

Source of Support: None; Conflict of Interest: None

(c) 
the Industrial Revolution. Besides, India's colonial masters forced laws that determine to the farmers, which crops exactly to cultivate and how much crops to cultivate. This led to a situation where no food crops were cultivated due to all the land was devoted to only for production of raw materials used for the industry's purpose. The end result was famine and poverty rise.

Hence, industrial revolution turned India into a source of rare, raw materials for British industries as well as a market for their finished products. The British only concentrated on the use of production factors and mass production for earning profit and collecting wealth for selfish development and it has led to a depletion of certain natural resources, leaving the environment permanently damaged and injured. One of the examples is deforestation, which is the clearing of forest trees for use in artificial commodity production. When the trees are finished, the wildlife in the forest also becomes threaded. The absence of trees or forest is only compounded by the problem of carbon emissions and bad weather or climate. Whereas forests would help emit the obligatory oxygen and refresh the levels of healthy gases in the atmosphere, factories and industries are emitting poisonous emissions and eliminate the source of oxygen. Pollution resulted from factories and industries involve not only airborne emissions, but land and water pollution also. The primary problem of global warming arises, resulting from various pollutions and carbon emissions. As the temperature rises, the glaciers and snow are melting and oceans are rising. Most animal species are becoming endangered or destroyed as a result of global warming. A good thing of the Industrial Revolution has certainly been the mass production of food for the globe's population.

The population has grown by algebraically due to the availability of food, at the same time the mass production of man-made and chemically altered food has also contributed to worldwide obesity and physical health problems. Besides, while the Industrial Revolution was the cause of positive transform for the industrial world, there is no question but other hand it has wreaked havoc on the environmental biodiversity and ecosystem services. The depletion of natural resources, carbon emissions, pollution of air, water and land with human health problems have resulted directly from the Industrial Revolution's accomplishments have only been disastrous for the earth environment.

The environmental issues in India become more serious every day like that lack of environmental education, reducing fertility of agricultural land, declining water level on earth, mass deforestation, land degradation, excess use of fertilizers and chemical in food production and river contamination and pollution. A true about India is 65 percent of the land is degraded in some way like nature or size and the infinite government policies do little to curb the damage. Some of the essential burning issues exist in Indian economy and whether or environment. First, Drought is very dangerous calamity stood in front of India because most of area covered by natural calamity of drought due to inadequate or lack of access to vital fresh water resources to the common people of the country. Furthermore, Indian economy in large scale depends on agriculture and allied sector. Second, Deforestation is one of the important issues exist in India in the form of overgrazing, indiscriminate felling of forest tree and over exploitation of land resources. The devastating effects of deforestation in India take account of soil, water and wind erosions, estimated to cost over 16,400 crores every year (FAO, 2009, p. 15).

Third point concern to air quality, India now has one of the worst qualities of air in the world. Without a doubt the main contributor of air pollution in India is the transportation system. Fourth, India appears to be digging its own grave deeper and quicker than the rest of us, nearly 30 percent of India's gross agricultural output is failing every year due to soil degradation, poor land management and counterproductive irrigation. Lastly, today's very burning issue of waste generation in not only in industrial work, but a person's house also and improper waste management deteriorates public health, destroy the quality of environmental life, and pollutes safe local air, land, and natural water resources (WTERT, 2012). Green economy is a design and remedy on sustainable development, environmental sustainability and environmental balance. It is against this backdrop, the present research study analyses the state of green economy and its linkages with sustainable development, environmental sustainability and environmental balance with reference to India. 
Important linkages between the concept of green economy and sustainable development are; in 2009, the UN General Assembly decided to hold a summit in Rio de Janeiro in 2012 to celebrate the $20^{\text {th }}$ anniversary of the first Rio Earth Summit in 1992. Two of the agenda items for Rio+20 are, "Green Economy in the context of Sustainable Development and Poverty Eradication," and "International Framework for Sustainable Development". With the green economy firmly established on the international policy agenda, it is useful to review and clarify the linkages between a green economy and sustainable development (Drexhage, John and Murphy, Deborah, 2010, P.17). Most interpretations of sustainability take as their starting point the consensus reached by the World Commission on Environment and Development (WCED) in 1987, which defined sustainable development as "Development that meets the needs of the present without compromising the ability of future generations to meet their own needs (WCED, 1987).

\section{Review of Research Literature}

Some of the important review of research studies relating to resent topic is as follows:

Dutt, Amitava Krishna and Rao, Mohan, J (1996) in their study considers the prospects for improving growth and income distribution that are broadly sustainable in terms of both macroeconomic and environmental constraints. According to the study, two-thirds of the workforce continues to derive their livelihood and many of their basic requirements of the primary sector. As a result, vast areas of semi-arid and fragile soil have been brought under the plow and close to $60 \%$ of agricultural land, therefore, are degraded to varying degrees.

Naidu, B.S.K (1996) in his article discusses about the potential of renewable energy in India with special reference to the electricity sector, captures its perspectives through SWOT analysis and explores the possibilities of tailoring renewable energy to a sustainable development program.

Mahapatra, Ajay and Mitchell, Paul. C (1997) in their research study has been discussed about the sustainable exploitation of non-wood forest resources as a means for achieving of natural forest conservation and income generation for rural inhabitants has drawn international attention in recent years. Accounting to authors India has a low forest productivity; $\left(0.7 \mathrm{~m}^{3}\right.$ ha per year $)$, low per capita forest availability (0.09 ha), high rural dependence on bio-energy $(68 \%)$, but is rich in flora and fauna (4000 species of trees, 15000 plant species in 64 million hectares of forests), and with a centuryold regulated management system. The country displays the tremendous potential to sustainably develop the non-wood products for the benefit of people and forests.

Lee, C.H (1998) in his research study has mentioned a way to prepare and formulate the resource depletion index as a result of this can be one amongst the vital quantitative tools to judge the extent of depletion of natural resources. The author has introduced two kinds of resource depletion indices, one is a world resource depletion index and also the second may be a local resource depletion index.

Bartelmus, Peter (1999) in his study has described an important environmental accounting system for finding environmental value and the cost of natural resource depletion in the Philippines. He has depicted the Causing effects of various types of pollution in Asia; two million people are dying annually.

Torras, Mariano (1999) in his study has discussed about various types of indices of accounting GDP with Human Well-being and social equality. The main theme of this study is that, to be completed, a social welfare indicator must reflect the wellbeing of both present and future generations. The HDI (Human Development Index) and PQLI (Physical quality of life index) are lacking in that they only account for the well-being of the present generation, while the sustainability theme in the WRI (World Resources Institute) studies reveals the author's exclusive concern with future generations.

Zpeteman, Kees (2001) in his study contributes to the debate from the viewpoint of a policymaker. Sustainable development is a dynamic concept and some say its greatest value is in striving for improvement in the decision-making process and the ability to build consensus.

In the view of the author, the goal of sustainable development, although impossible to achieve without a high consensus-building ability of social parties, is an expression of the desire to uplift our 
society to a higher level of individual and collective consciousness and responsibility.

Gundimeda, Haripriya; Sanyal, Sanjeev; Sinha, Rajiv and Sukhdev, Pavan (2006) in a their study have depicted the importance of GAISP (Green Accounting for Indian States and Union Territories Project). GAISP proposes to build a framework of adjusted national accounts that represent genuine net additions to the national wealth. System of environmentally-adjusted national income accounts will not only reflect in economic accounts will not only reflect in economic terms the depletion of natural resources and the health cost of pollution but also reward additions to the stock of human capital through education. 'Green Accounts' for India and its states will provide a much better measure of development compared to GDP growth percentage and GSDP (Gross State Domestic Product) growth measures.

Srivastava, Leena (2006) in her study opines that climate is one of the important factors of sustainable development. Today's climate change is a major challenge stand in front of the world. Even global warming is bad consequences of climate change. She argues that high $\mathrm{CO}_{2}$ emission is one of the major causes of global warming. India is part of the NonAnnex I group of countries with no obligation to reduce her emissions of greenhouse gases (GHG) in the first commitment period, 2008-12. India however is the fifth largest energy consumer in the world with carbon dioxide emissions in 2003 amounting to 1050 million tons (MT).

Srivastava, Leena and Rehman, I.H. (2006) in their research has described the importance of energy for sustainable development. There is a positive relationship between excess availability of energy and economic development of developed or developing countries. In India, 741 million people lived in rural areas and the UNDP, HDR reports human poverty value of $31.4 \%$ for 2004 , India ranks $48^{\text {th }}$ among 95 developing countries on poverty level. In this context, inequitable access to clean energy sources in the country is a major impediment to sustainable development.

The foregoing review of research studies reveals that, there are some researches studies on the present research topic have been carried out. More importantly, these are a very small so far as their scope is concerned. Hence there is an urgent need to undertake a large and depth in scope research study on the topic into our consideration. We did not find a single study that examines the strategy or a design of the green economy within the framework of its areas and indicators useful for sustainable development and environmental sustainability. It will be a unique and important contribution to the research in environmental economics and will be helpful for policy formulation and implementation as well.

\section{Research Methodology}

The major objectives of the present research study are as follows:

1. To study the theoretical issues relating to a green economy;

2. To examine the nature and extent of a green economy as a design for sustainable development achieved by the India;

3. To identify the areas of concentration for achieving a green economy for India and suggest measures useful for sustainable development and environmental sustainability.

The hypotheses of the present research study are as follows:

\section{India is not rigorous and sincere in achieving a green economy}

The present research work depends on the time series secondary data provided by the World Bank (National Development Indicators). This study considers the appropriate indicators of environmental, human well-being and social equity relating to a green economy of India. Therefore, it is purely an analytical and a comparative type of research study. This research study examines the international concept of "Green Economy" with reference to India, useful for environmental sustainability.

This research study highlights three principal areas of a green economy and their indicators and the key challenges to developing a framework for metrics for a green economy. While countries require flexibility to meet their different needs and green economy pathway, the development and coordination of enabling conditions at the international level 
require some degree of standardization and comparability (UNEP, 2011, p.3). The metrics framework of a green economy is given by the UNEP with identified three principal areas and the number of indicators of a green economy, within these areas. A green economy is first and foremost about transforming the way economies grow currently. Growth is typically generated from investments in high emission, heavily polluting, waste generating, resource intensive and ecosystem damaging activities. A green economy requires investment to shift towards low carbon, clean energy, waste minimizing, resource efficient and ecosystem enhancing activities. The key Indicators of economic transformation, Indicators of Resource Efficiency, Indicators of Progress and Well-being have been considered by this study.

This analytical research study wholly depends on the secondary data. The necessary and essential secondary data have been collected from World Bank Reports, Government Publications, Reputed Journals and Various Reports, Research papers and articles. The major sources of secondary data are the World Bank, Ministry of Environment and Forest Reports and Websites, UNEP Reports about Green Economy; also the their data sources are OECD, UNDP, and SEEA etc. The secondary data has collected for the period from 2000 to 2015 relating to India. The important and suitable statistical software's have been used for the data processing and analysis purpose, namely SPSS, Excel, etc. The necessary and appropriate tools have been used for the data analysis, which include, Coefficient of Variation, Simple and Compound Growth Rate, Ratio Analysis, etc. Along with these techniques, for the hypothesis testing purpose the researcher has used " $\mathrm{t}$ " test as per the needs requirements and suitability of the method. The period of the present research study is from 2000 to 2015 . The data relating to the areas and indicators of a green economy have given by UNEP. In the case of non-availability and inadequate availability of the necessary data, the data relating to nearer and dummy variables as indicators of a green economy also has been used for the analysis of the nature and extent of the green economy of India. Research study makes use of the following actual and appropriate indicators of a green economy from its areas, which are nearer to the original indicators.
1. Economic Transformation: Improved Sanitation Facility (\% of population with access), Adjusted savings: natural resources depletion ( $\%$ of GNI), Total renewable electricity generation (In billion kilowatt hours), Total $\mathrm{CO}_{2}$ emissions from consumption of energy (In million metric tons), Improved water source (\% of population with access).

2. Resource Efficiency: Agricultural raw materials exports (\% of merchandise exports), Electric power consumption (kWh Per capita), Forest rents (\% of GDP), Energy use ( $\mathrm{kg}$ of oil equivalent per capita), Total natural resources rents (\% of GDP).

3. Human Well-being: GNI per capita growth (annual \%), Health expenditure, total (private + public) (\% of GDP), The employment to population ratio, $15+$, total (\%) modeled ILO estimation, Life expectancy at birth, total (years), Household final consumption expenditure per capita growth (Annual \%)

\section{RESULTS AND DISCUSSION}

This section of the paper presents the results and discussion about the green economy of India for the sustainable development and environmental sustainability.

\section{(A) Green Economy Indicators of Economic Transformation}

\section{Adjusted Saving: Natural Resources Depletion}

Resource depletion means the consumption of a resource faster than it can be replenished. Here Natural resource depletion is the sum of net forest depletion, energy depletion, and mineral depletion.

Table 1: Adjusted Saving: Natural Resources Depletion

\begin{tabular}{cccc}
\hline \multicolumn{3}{c}{ Adjusted Saving: Natural Resources Depletion } \\
\hline $\begin{array}{c}\text { S1. } \\
\text { No. }\end{array}$ & Year & \% of GNI & $\begin{array}{c}\text { Net Annual Percentage } \\
\text { Change (\%) }\end{array}$ \\
\hline 1 & 2000 & 2.83 & 0.00 \\
2 & 2001 & 2.72 & -0.11 \\
3 & 2002 & 2.69 & -0.03 \\
4 & 2003 & 2.73 & 0.04 \\
5 & 2004 & 2.86 & 0.13 \\
6 & 2005 & 3.02 & 0.16 \\
7 & 2006 & 3.62 & 0.6 \\
8 & 2007 & 4.04 & 0.42
\end{tabular}




\begin{tabular}{|c|c|c|c|}
\hline 9 & 2008 & 5.55 & 1.51 \\
\hline 10 & 2009 & 3.01 & -2.54 \\
\hline 11 & 2010 & 4.19 & 1.18 \\
\hline 12 & 2011 & 4.26 & 0.07 \\
\hline 13 & 2012 & 3.23 & -1.03 \\
\hline 14 & 2013 & 3.14 & -0.09 \\
\hline 15 & 2014 & 4.12 & 0.98 \\
\hline 16 & 2015 & 4.22 & 0.10 \\
\hline \multicolumn{2}{|c|}{ C.G.R } & \multicolumn{2}{|c|}{$3.00 \%$} \\
\hline \multicolumn{2}{|c|}{ MEAN } & \multicolumn{2}{|c|}{3.51} \\
\hline \multicolumn{2}{|c|}{ C.V } & \multicolumn{2}{|c|}{$23 \%$} \\
\hline
\end{tabular}

Source: World Bank staff estimates based on sources and methods in the World Bank's "The Changing Wealth of Nations: Measuring Sustainable Development in the New Millennium"-2011 and World development Indicators-last updated: 19/07/2016).

The analysis of data results reveals that natural resource depletion took place in India at 3 percent CGR, is at marginal rate during 2000 to 2015, with an average of 3.51 percent. It took place consistently as indicated by C.V of 23 percent. Thus, the depletion of natural resources in India was not over or excessive is a move towards a green economy in connection with the indicator of natural resource depletion. This positive economic transformation is useful for reaching towards green economy for India. The rate of depletion of natural resources in India is lesser than other developing countries as well as developed countries of the world also.

\section{Improved Sanitation Facilities}

Sanitation is very essential and needful thing for healthy and well life. Even the efficacy of mental or physical labor depends on their health and wellness then these both important things wholly depend on Sanitation or cleanness. The lack of hygiene, sanitation and contributes to arise problems in a range of health and environmental (WHO-UNICEF, 2010. p. 4).

Table 2: Improved Sanitation Facilities

\begin{tabular}{cccc}
\hline \multicolumn{4}{c}{ Improved Sanitation Facilities } \\
\hline S1. No. & Year & $\begin{array}{c}\text { \% of Population } \\
\text { with Access }\end{array}$ & $\begin{array}{c}\text { Net Annual Percentage } \\
\text { Change (\%) }\end{array}$ \\
\hline 1 & 2000 & 26 & 0.00 \\
2 & 2001 & 26 & 0.00 \\
3 & 2002 & 27 & 1.00 \\
4 & 2003 & 28 & 1.00 \\
5 & 2004 & 29 & 1.00
\end{tabular}

\begin{tabular}{cccc}
6 & 2005 & 30 & 1.00 \\
7 & 2006 & 31 & 1.00 \\
8 & 2007 & 32 & 1.00 \\
9 & 2008 & 33 & 1.00 \\
10 & 2009 & 33 & 0.00 \\
11 & 2010 & 34 & 1.00 \\
12 & 2011 & 35 & 1.00 \\
13 & 2012 & 36 & 1.00 \\
14 & 2013 & 37 & 1.00 \\
15 & 2014 & 38 & 1.00 \\
16 & 2015 & 39 & 1.00 \\
\hline \multicolumn{5}{c}{ C.G.R } \\
\hline \multicolumn{5}{c}{ MEAN } \\
\hline \multicolumn{3}{c}{$3.00 \%$} \\
\hline
\end{tabular}

Source: WHO/UNICEF Joint Monitoring Programme (JMP) for Water Supply and Sanitation -http://www.wssinfo.org/ and World development Indicators-last updated: 19/07/2016.

Improved sanitation facilities bring about economic transformation and thereby a green economy. The analysis of data results reveals that the state of sanitation facilities in India is not very much happy and satisfactory. The access to sanitation facilities in India is only to 32 percent. They grew at the rate of only 3 percent per annum. But a considerable consistency is found in the improvement of sanitation facilities as indicated by C.V of 13 percent. The exclusive conclusion can be drawn is, India has failed in achieving expected and desirable sanitation facilities, hence economic transformation and thereby green economy for India.

\section{Improved Water Source}

Millennium Development Goals determined the objective of, to provide the clean drinking water to all people of the World up to 2015 (MDG, United Nations, 2012. p.52). But before MDG formulation, More than half of Indian population has access to the unsafe drinking water for daily use due to lack of availability of clean water source and poverty.

Table 3: Improved Water Source

\begin{tabular}{cccc}
\hline \multicolumn{4}{c}{ Improved Water Source } \\
\hline S1. No. & Year & $\begin{array}{c}\text { \% of Population } \\
\text { with Access }\end{array}$ & $\begin{array}{c}\text { Net Annual Percentage } \\
\text { Change (\%) }\end{array}$ \\
\hline 1 & 2000 & 81 & 0.00 \\
2 & 2001 & 82 & 1.00 \\
3 & 2002 & 83 & 1.00 \\
4 & 2003 & 84 & 1.00
\end{tabular}




\begin{tabular}{cccc}
5 & 2004 & 85 & 1.00 \\
6 & 2005 & 86 & 1.00 \\
7 & 2006 & 87 & 1.00 \\
8 & 2007 & 88 & 1.00 \\
9 & 2008 & 89 & 1.00 \\
10 & 2009 & 90 & 1.00 \\
11 & 2010 & 91 & 1.00 \\
12 & 2011 & 92 & 1.00 \\
13 & 2012 & 93 & 1.00 \\
14 & 2013 & 94 & 1.00 \\
15 & 2014 & 95 & 1.00 \\
16 & 2015 & 96 & 1.00 \\
\hline \multicolumn{5}{c}{ C.G.R } \\
\hline \multicolumn{3}{c}{ MEAN } \\
\hline \multicolumn{3}{c}{ C.V } \\
\hline
\end{tabular}

Source: WHO/UNICEF Joint Monitoring Programme (JMP) for Water Supply and Sanitation -http://www.wssinfo.org/ and World development Indicators-last updated: 19/07/2016.

Water resource is a very important natural resource, is a must for survival of all living things in general and human beings in particular. The examination of data results relating to access to water shows, it is good for India, but not better which stood at
89 percent on an average, grew at only meager rate of 1 percent per annum with consistency indicated by C.V of 5 percent. This is adequate and clear indication that, India has failed in providing drinking water, consequently economic transformation and green economy for India.

\section{Total $\mathrm{CO}_{2}$ Emissions from Consumption of Energy}

After the beginning of the industrial revolution, the level of carbon dioxide has been rapidly increasing in the atmosphere. About the India, estimates have been made of the carbon dioxide $\left(\mathrm{CO}_{2}\right)$ emission into the atmosphere through the combustion of non-fossil and fossil fuels for the period 1950-1982.

$\mathrm{CO}_{2}$ emission is a hindrance in achieving desirable economic transformation and consequently green economy. The data results reveal that the discharge of $\mathrm{CO}_{2}$ into atmosphere by India is no doubt grew significantly (1454 MT), which also grew at the harmful rate of 6 percent per annum. Likewise, per capita $\mathrm{CO}_{2}$ emission of India also grew at considerable rate of 4 percent per annum, with

Table 4: Total $\mathrm{CO}_{2}$ Emissions from Consumption of Energy

\begin{tabular}{|c|c|c|c|c|c|c|}
\hline \multicolumn{7}{|c|}{ Total $\mathrm{CO}_{2}$ Emissions From Consumption of Energy } \\
\hline S1. No & Year & $\begin{array}{c}\text { In Million } \\
\text { Metric Tons } \\
(000,000)\end{array}$ & $\begin{array}{c}\text { Annual \% } \\
\text { Change }\end{array}$ & $\begin{array}{c}\text { Indian Population } \\
\text { In Crore } \\
(00,00,000)\end{array}$ & $\begin{array}{c}\text { Annual \% } \\
\text { Change }\end{array}$ & $\begin{array}{l}\text { Per Capita } \\
\mathrm{Co}_{2} \text { Emission } \\
\text { (Tons) }\end{array}$ \\
\hline 1 & 2000 & 991 & 0.00 & 101.4 & 0.00 & 0.98 \\
\hline 2 & 2001 & 1016 & 3.00 & 102.9 & 2.00 & 0.99 \\
\hline 3 & 2002 & 1008 & -1.00 & 104.6 & 2.00 & 0.96 \\
\hline 4 & 2003 & 1022 & 1.00 & 105.1 & 0.37 & 0.97 \\
\hline 5 & 2004 & 1121 & 10 & 106.6 & 1.00 & 1.05 \\
\hline 6 & 2005 & 1181 & 5.00 & 108.1 & 1.00 & 1.09 \\
\hline 7 & 2006 & 1281 & 8.00 & 109.6 & 1.00 & 1.17 \\
\hline 8 & 2007 & 1366 & 7.00 & 113.1 & 3.00 & 1.21 \\
\hline 9 & 2008 & 1449 & 6.00 & 114.8 & 2.00 & 1.26 \\
\hline 10 & 2009 & 1643 & 13 & 116.7 & 2.00 & 1.41 \\
\hline 11 & 2010 & 1715 & 4.00 & 117.3 & 1.00 & 1.46 \\
\hline 12 & 2011 & 1753 & 2.00 & 119.1 & 1.00 & 1.47 \\
\hline 13 & 2012 & 1831 & 4.00 & 121.1 & 1.00 & 1.52 \\
\hline 14 & 2013 & 1885 & 3.00 & 122.1 & 1.00 & 1.54 \\
\hline 15 & 2014 & 1963 & 4.00 & 123.7 & 1.00 & 1.59 \\
\hline 16 & 2015 & 2041 & 4.00 & 130.1 & 5.00 & 1.57 \\
\hline \multicolumn{2}{|c|}{ C.G.R } & $6.00 \%$ & & $2.00 \%$ & & $4.00 \%$ \\
\hline \multicolumn{2}{|c|}{ MEAN } & 1454 & & 113.5 & & 2.27 \\
\hline \multicolumn{2}{|c|}{ C.V } & $26 \%$ & & $7.00 \%$ & & $19 \%$ \\
\hline
\end{tabular}

Source: 1-U.S Energy information administration -http://www.eia.gov and World development Indicators-last updated: 19/07/2016. 2-Population Statistics Source: Central Intelligence Agency, Washington, D.C. 
per capita emission of 2.27 tons indicates a signal of danger. This shows even $\mathrm{CO}_{2}$ emission is not highly intensive there is need for the control of $\mathrm{CO}_{2}$ emission for desirable economic transformation and green economy for India also.

\section{Total Renewable Electricity Generation}

World Walk and run through energy, therefore all countries have been engaged in energy and electricity generation help of natural resources like coal, oil, gas, timber etc. But this conventional energy is harmful to environment and ecosystem services of respective country.

Renewable energy is a positive economic transformation, which further facilitates in achieving green economy. It is a well known fact that the generation as well as supply of energy is dominated by thermal and not by renewable energy. This is adequately proved that renewable energy generation (124 BKh) and per capita availability (1.8 Khr) are sufficiently inadequate and shortfall. Hence growth rate (CGR: 5 percent) of renewable energy generation in India is considerable but not significant at all. This requires paying due attention towards renewable energy generation and thereby desirable economic transformation and green economy for India.

\section{(B) Green Economy Indicators of Resource Efficiency}

\section{Agricultural Raw Material Export}

Agriculture has been the backbone of Indian Economy because of before the independence period and after the two decades of independence, around 72 percent of total working population was engaged in agriculture. Similarly, share of agriculture in total merchandise exports also essential for improving the balance of trade.

Even though India is an agricultural country, it could not exploit agriculture optimally and efficiently. Hence its export of agricultural raw materials stood at less than two percent of merchandise exports. But the noteworthy thing is growth in agriculture raw material exports was considerable which stood at 4 percent. But consistency in exports was not there

Table 5: Total Renewable Electricity Generation

\begin{tabular}{|c|c|c|c|c|c|c|}
\hline \multicolumn{7}{|c|}{ Total Renewable Electricity Generation } \\
\hline Sl. No & Year & $\begin{array}{c}\text { In Billion } \\
\text { Kilowatt Hours } \\
(000,000,000)\end{array}$ & $\begin{array}{c}\text { Annual \% } \\
\text { Change }\end{array}$ & $\begin{array}{c}\text { Indian Population } \\
\text { In Crore } \\
(00,00,000)\end{array}$ & $\begin{array}{c}\text { Annual \% } \\
\text { Change }\end{array}$ & $\begin{array}{c}\text { Per Capita } \\
\text { Renewable Electr. } \\
\text { Generation (Khr.) }\end{array}$ \\
\hline 1 & 2000 & 77 & 0.00 & 101.4 & 0.00 & 76 \\
\hline 2 & 2001 & 77 & 0.00 & 102.9 & 2.00 & 75 \\
\hline 3 & 2002 & 68 & -12 & 104.6 & 2.00 & 65 \\
\hline 4 & 2003 & 80 & 18 & 105.1 & 0.37 & 76 \\
\hline 5 & 2004 & 90 & 13 & 106.6 & 1.00 & 85 \\
\hline 6 & 2005 & 109 & 21 & 108.1 & 1.00 & 101 \\
\hline 7 & 2006 & 123 & 13 & 109.6 & 1.00 & 112 \\
\hline 8 & 2007 & 133 & 8.00 & 113.1 & 3.00 & 118 \\
\hline 9 & 2008 & 125 & -6.00 & 114.8 & 2.00 & 109 \\
\hline 10 & 2009 & 123 & -2.00 & 116.7 & 2.00 & 105 \\
\hline 11 & 2010 & 135 & 10 & 117.3 & 1.00 & 115 \\
\hline 12 & 2011 & 160 & 19 & 119.1 & 1.00 & 135 \\
\hline 13 & 2012 & 160 & 0.00 & 121.1 & 1.00 & 133 \\
\hline 14 & 2013 & 166 & 4.00 & 122.1 & 1.00 & 136 \\
\hline 15 & 2014 & 174 & 5.00 & 123.7 & 1.00 & 141 \\
\hline 16 & 2015 & 182 & 5.00 & 130.1 & 5.00 & 140 \\
\hline \multicolumn{2}{|c|}{ C.G.R } & $7.00 \%$ & & $2.00 \%$ & & $5.00 \%$ \\
\hline \multicolumn{2}{|c|}{ MEAN } & 124 & & 113.5 & & 108 \\
\hline \multicolumn{2}{|c|}{ C.V } & $30 \%$ & & $7.00 \%$ & & $24 \%$ \\
\hline
\end{tabular}

Source: 1-U.S Energy information administration -http://www.eia.gov and World development Indicators-last updated: 19/07/2016. 2-Population Statistics Source: Central Intelligence Agency, Washington, D.C. 
as indicated by the C.V of 25 percent. Thus India did not succeed in efficiently using agriculture as the natural resource and marching towards a green economy.

Table 6: Agricultural Raw Material Export

\begin{tabular}{|c|c|c|c|}
\hline \multicolumn{4}{|c|}{ Agricultural Raw Material Export } \\
\hline \multirow[t]{2}{*}{ S1. No. } & \multirow[t]{2}{*}{ Year } & $\begin{array}{c}\% \text { of } \\
\text { Merchandise }\end{array}$ & $\begin{array}{l}\text { Net Annual } \\
\text { Percentage }\end{array}$ \\
\hline & & Exports & Change $(\%)$ \\
\hline 1 & 2000 & 1.26 & 0.00 \\
\hline 2 & 2001 & 1.14 & -0.12 \\
\hline 3 & 2002 & 1.06 & -0.08 \\
\hline 4 & 2003 & 1.08 & 0.02 \\
\hline 5 & 2004 & 1.20 & 0.12 \\
\hline 6 & 2005 & 1.27 & 0.07 \\
\hline 7 & 2006 & 1.72 & 0.45 \\
\hline 8 & 2007 & 1.98 & 0.26 \\
\hline 9 & 2008 & 1.74 & -0.24 \\
\hline 10 & 2009 & 1.16 & -0.58 \\
\hline 11 & 2010 & 2.01 & 0.85 \\
\hline 12 & 2011 & 1.83 & -0.18 \\
\hline 13 & 2012 & 1.95 & 0.12 \\
\hline 14 & 2013 & 2.06 & 0.11 \\
\hline 15 & 2014 & 1.57 & -0.49 \\
\hline 16 & 2015 & 2.03 & 0.46 \\
\hline \multicolumn{2}{|c|}{ C.G.R } & \multicolumn{2}{|c|}{$4.00 \%$} \\
\hline \multicolumn{2}{|c|}{ MEAN } & \multicolumn{2}{|c|}{1.57} \\
\hline \multicolumn{2}{|c|}{ C.V } & \multicolumn{2}{|c|}{$25 \%$} \\
\hline
\end{tabular}

Source: World Bank staff estimates from the Comtrade database maintained by the United Nations Statistics Division and World development Indicators-last updated: 19/07/2016.

\section{Electric Power Consumption}

A hundred years ago, people had never imagined that they would make lives very simple and painless through using technology. Similarly, in the modern era, people cannot imagine their lives without electricity. Because today's, all functions of society requires help of electric power.

Table 7: Electric Power Consumption

\begin{tabular}{cccc}
\hline \multicolumn{4}{c}{ Electric Power Consumption } \\
\hline $\begin{array}{c}\text { S1. } \\
\text { No. }\end{array}$ & Year & KWh Per Capita & $\begin{array}{c}\text { Annual Percentage } \\
\text { Change (\%) }\end{array}$ \\
\hline 1 & 2000 & 399 & 0.00 \\
2 & 2001 & 400 & 0.25 \\
3 & 2002 & 417 & 4.00 \\
4 & 2003 & 437 & 5.00 \\
5 & 2004 & 459 & 5.00 \\
6 & 2005 & 477 & 4.00 \\
7 & 2006 & 519 & 9.00
\end{tabular}

\begin{tabular}{|c|c|c|c|}
\hline 8 & 2007 & 553 & 7.00 \\
\hline 9 & 2008 & 574 & 4.00 \\
\hline 10 & 2009 & 614 & 7.00 \\
\hline 11 & 2010 & 657 & 7.00 \\
\hline 12 & 2011 & 713 & 9.00 \\
\hline 13 & 2012 & 760 & 7.00 \\
\hline 14 & 2013 & 750 & -1.00 \\
\hline 15 & 2014 & 780 & 4.00 \\
\hline 16 & 2015 & 810 & 4.00 \\
\hline \multicolumn{2}{|c|}{ C.G.R } & \multicolumn{2}{|c|}{$5.00 \%$} \\
\hline \multicolumn{2}{|c|}{ MEAN } & \multicolumn{2}{|c|}{582} \\
\hline \multicolumn{2}{|c|}{ C.V } & \multicolumn{2}{|c|}{$25 \%$} \\
\hline
\end{tabular}

Source: International Energy Agency (IEA Statistics, OECD/ IEA, http://www.iea.org/stats/index.asp and World development Indicators-last updated: 19/07/2016.

Electricity is necessary both for production as well as consumption activity. Electricity consumption is also an indicator of standard of living of people in the country. It is revealed that electricity consumption in India is meager ( $582 \mathrm{KWh}$ ) compared to developed countries. But the noteworthy thing is electricity consumption is growing at the considerable rate of 5 percent per annum, is a good thing. Even though, variations is found in electricity consumption as indicated by C.V (25\%), those were positive changes in electricity consumption, is also necessary to be taken in to account. Thus electricity consumption in India is lesser, but it is growing considerably and contributing to resource efficiency as well as attaining of green economy.

\section{Energy Use}

'Energy use' refers to use of primary energy before transformation to other end-use fuels. Energy use growth is directly linked to well-being and prosperity across the globe. But today's key challenge stood that meeting the environmentally secure and sufficient energy to increased demand (Imperial, 2016).

Table 8: Energy Use

\begin{tabular}{cccc}
\hline \multicolumn{4}{c}{ The Energy Use } \\
\hline S1. No. & Year & $\begin{array}{c}\text { Kg of Oil Equivalent } \\
\text { Per Capita }\end{array}$ & $\begin{array}{c}\text { Annual } \\
\text { Percentage } \\
\text { Change (\%) }\end{array}$ \\
\hline 1 & 2000 & 438 & 0.00 \\
2 & 2001 & 438 & 0.00 \\
3 & 2002 & 444 & 1.00 \\
4 & 2003 & 448 & 1.00 \\
5 & 2004 & 466 & 4.00
\end{tabular}




\begin{tabular}{|c|c|c|c|}
\hline 6 & 2005 & 479 & 3.00 \\
\hline 7 & 2006 & 498 & 4.00 \\
\hline 8 & 2007 & 521 & 5.00 \\
\hline 9 & 2008 & 538 & 3.00 \\
\hline 10 & 2009 & 585 & 9.00 \\
\hline 11 & 2010 & 599 & 2.00 \\
\hline 12 & 2011 & 616 & 3.00 \\
\hline 13 & 2012 & 637 & 3.00 \\
\hline 14 & 2013 & 643 & 1.00 \\
\hline 15 & 2014 & 661 & 3.00 \\
\hline 16 & 2015 & 679 & 3.00 \\
\hline \multicolumn{2}{|c|}{ C.G.R } & \multicolumn{2}{|c|}{$3.00 \%$} \\
\hline \multicolumn{2}{|c|}{ MEAN } & \multicolumn{2}{|c|}{543} \\
\hline \multicolumn{2}{|c|}{ C.V } & \multicolumn{2}{|c|}{$16 \%$} \\
\hline
\end{tabular}

Source: International Energy Agency (IEA Statistics, OECD/ IEA, http://www.iea.org/stats/index.asp and World development Indicators-last updated: 19/07/2016.

Energy is very important resource or input useful for both the production as well as consumption. It is a good indicator of standard of living of people in the country. It is clear that energy consumption in India is meager and inadequate $(543 \mathrm{Kg}$ oil equivalent per capita). Besides this, it grew at only the marginal rate of 3 percent per annum. Even consistency in energy consumption was found, the growth as well as quantity of energy being consumed in India is meager and hence insignificant only. Thus India has failed in using energy as resource efficiently and hence attaining of green economy.

\section{Forest Rents}

Forest is engine of green economy because without any injury to earth it has been contributing in sustainable and inclusive development of the World. In India, forests are classified into four major groups, namely tropical, sub-tropical, temperate, and alpine which is covered 67,705 thousand hectares $(20.59 \%)$ land under the forest out of 328.7 Mha (million hectares) total Indian land (FAO, 2005). Forests are providing multiple uses and benefits to us without disturbing and degrading any environment system (GIST, 2005. p.10).

Table 9: Forest Rents

\begin{tabular}{cccc}
\hline \multicolumn{3}{c}{ The Forest Rents } \\
\hline S1. No. & Year & \% of GDP & $\begin{array}{c}\text { Net Annual Percentage } \\
\text { Change (\%) }\end{array}$ \\
\hline 1 & 2000 & 1.64 & 0.00 \\
2 & 2001 & 1.58 & -0.06 \\
3 & 2002 & 1.79 & 0.21
\end{tabular}

\begin{tabular}{cccc}
4 & 2003 & 1.64 & -0.15 \\
5 & 2004 & 1.17 & -0.47 \\
6 & 2005 & 1.01 & -0.16 \\
7 & 2006 & 1.37 & 0.36 \\
8 & 2007 & 1.45 & 0.08 \\
9 & 2008 & 1.44 & -0.01 \\
10 & 2009 & 1.20 & -0.24 \\
11 & 2010 & 1.80 & 0.60 \\
12 & 2011 & 1.65 & -0.15 \\
13 & 2012 & 1.28 & -0.37 \\
14 & 2013 & 1.36 & 0.08 \\
15 & 2014 & 1.36 & 0.00 \\
16 & 2015 & 1.35 & -0.01 \\
\hline \multicolumn{3}{c}{ C.G.R } \\
\hline \multicolumn{3}{c}{ MEAN } \\
\hline \multicolumn{3}{c}{ C.V } \\
\hline
\end{tabular}

Source: Estimates based on sources and methods described in "The Changing Wealth of Nations: Measuring Sustainable Development in the New Millennium"-World Bank, 2011 and World development Indicators-last updated: 19/07/2016.

Economic rents of forest measure help to stumpage value or forest charges. This "residual value" approach is the methodology used in many countries around the World to estimate economic rents and stumpage prices or forest charges (FAO, 2016, p. 5). The only costs of depletion considered in the 1968 SNA are the extraction costs and records the potential loss in forest wealth as other changes in assets that have no effect on GDP. Hence, there is a need for incorporating the forest resources into the national accounts (FAO, 2016, p.10).

Forest is a very important natural resource on various grounds. Hence it is logical and scientific to consider the area under forests and extract forest rents. The data results reveal that the forest rents derived by India is meager only. It stood at only 1.44 percent of GDP on an average. Even it was consistent, it showed a negative growth only in extracting forest rents. Thus, India could not use forests as natural resource efficiency and thereby to the green economy.

\section{Total Natural Resources Rents}

Total natural resource rents are the sum of oil rents, natural gas rents, coal rents (hard and soft), mineral rents, and forest rents. Economic outputs of these natural resources are very important in building the framework for sustainable development. Natural resources give rise to economic rents because they are not produced (BLUENOMICS, 2016, Web.p.1). 
Table 10: Total Natural Resources Rents

\begin{tabular}{cccc}
\hline \multicolumn{4}{c}{ Total Natural Resources Rents } \\
\hline S1. No. & Year & \% of GDP & $\begin{array}{c}\text { Net Annual Percentage } \\
\text { Change (\%) }\end{array}$ \\
\hline 1 & 2000 & 3.82 & 0.00 \\
2 & 2001 & 3.89 & 0.07 \\
3 & 2002 & 3.62 & -0.27 \\
4 & 2003 & 3.79 & 0.17 \\
5 & 2004 & 4.46 & 0.67 \\
6 & 2005 & 4.88 & 0.42 \\
7 & 2006 & 5.51 & 0.63 \\
8 & 2007 & 6.15 & 0.64 \\
9 & 2008 & 9.18 & 3.03 \\
10 & 2009 & 4.61 & -4.57 \\
11 & 2010 & 6.26 & 1.65 \\
12 & 2011 & 6.67 & 0.41 \\
13 & 2012 & 5.06 & -1.61 \\
14 & 2013 & 4.85 & -0.21 \\
15 & 2014 & 6.60 & 1.75 \\
16 & 2015 & 6.79 & 0.19 \\
\hline \multicolumn{3}{c}{ C.G.R } \\
\hline \multicolumn{3}{c}{ MEAN } \\
\hline \multicolumn{3}{c}{ C.V } \\
\hline
\end{tabular}

Source: Estimates based on sources and methods described in "The Changing Wealth of Nations: Measuring Sustainable Development in the New Millennium"-World Bank, 2011 and World development Indicators-last updated: 19/07/2016.

The estimates of natural resources rents shown are calculated as the difference between the price of a commodity and the average cost of producing it. This is done by estimating the world price of units of specific commodities and subtracting estimates of average unit costs of extraction or harvesting costs (including a normal return on capital). These unit rents are then multiplied by the physical quantities of countries extract or harvest to determine the rents for each commodity as a share of gross domestic product (GDP). Resource rent may be divided between depletion and return to natural capital (BLUENOMICS, 2016, Web.p.1).

Natural resources are very important in all respects, besides their shortage and scarcity. Hence it is expected their proper utilization and extraction and thereby deriving rents from them. The data results shows that India has derived natural resource rents marginally only at 5.38 percent of GDP. Likewise, the rate of growth of deriving forest rents was also marginal only 4 percent CGR. It was very much inconsistent to derive forest rents by India as indicated by the C.V of 28 percent. Thus the foregoing analysis adequately reveals that India did not succeed much in efficiently using natural resources necessary for realizing green economy.

\section{(C) Green Economy Indicators of Human Well- being}

\section{Gross National Income Per Capita Growth}

The gross national income (GNI) is the total domestic and foreign output claimed by residents of a country, consisting of gross domestic product (GDP) plus factor incomes earned by foreign residents, minus income earned in the domestic economy by nonresidents. Comparing the GNI and GDP (Wikipedia, 2016). The per capita GNI is most essential element of showing the economic and social development in respective area or country.

Table 11: Gross National Income Per Capita Growth

\begin{tabular}{|c|c|c|c|}
\hline \multicolumn{4}{|c|}{ GNI Per Capital Growth } \\
\hline Sl. No. & Year & Annual \% & $\begin{array}{c}\text { Net Annual Percentage } \\
\text { Change (\%) }\end{array}$ \\
\hline 1 & 2000 & 1.83 & 0.00 \\
\hline 2 & 2001 & 3.32 & 1.49 \\
\hline 3 & 2002 & 2.35 & -0.97 \\
\hline 4 & 2003 & 6.09 & 3.74 \\
\hline 5 & 2004 & 6.34 & 0.25 \\
\hline 6 & 2005 & 7.66 & 1.32 \\
\hline 7 & 2006 & 7.65 & -0.01 \\
\hline 8 & 2007 & 8.70 & 1.05 \\
\hline 9 & 2008 & 2.33 & -6.37 \\
\hline 10 & 2009 & 7.07 & 4.74 \\
\hline 11 & 2010 & 8.33 & 1.26 \\
\hline 12 & 2011 & 5.48 & -2.85 \\
\hline 13 & 2012 & 3.45 & -2.03 \\
\hline 14 & 2013 & 5.52 & 2.07 \\
\hline 15 & 2014 & 6.13 & 0.61 \\
\hline 16 & 2015 & 6.79 & 0.66 \\
\hline \multicolumn{2}{|c|}{ C.G.R } & \multicolumn{2}{|r|}{$4.00 \%$} \\
\hline \multicolumn{2}{|c|}{ MEAN } & \multicolumn{2}{|r|}{5.57} \\
\hline \multicolumn{2}{|c|}{ C.V } & \multicolumn{2}{|r|}{$40 \%$} \\
\hline
\end{tabular}

Source: World Bank national accounts data and OECD National Accounts data files and World development Indicators-last updated: 19/07/2016.

GNI per capita is an indicator of standard of living of the people and thereby human wellbeing. The analysis of data results reveals that India could grow moderately at average rate of 5.57 percent CGR only. The growth rate is good, but not better and far away from the best. Its CGR for 2000 to 
2015 was just moderate of 4 percent. But the GNI per capita growth was inconsistent as shown by C.V of 40 percent during the study period. Hence India could not do better through GNI per capita growth for promoting wellbeing of the people in the society. It is a thing of concern for human wellbeing and consequently green economy for India.

\section{Employment to Population Ratio}

Employment is the major indicator of economic and social development because it eradicates poverty and endeavors to attain the sustainability in inclusive development. Current era raised new concept of green jobs, e.g., employment generation in solar power equipment technology, wind energy,geothermal energy, biomass and energy from waste. But accounting of only green job generation for evaluating performance of respective country concern to a green economy is difficult due to lack of availability data, hence the researcher has used the dummy parameter of total employment.

Table 12: Employment to Population Ratio

\begin{tabular}{|c|c|c|c|}
\hline \multicolumn{4}{|c|}{ Employment to Population Ratio, 15+, Total } \\
\hline $\begin{array}{l}\text { Sl. } \\
\text { No. }\end{array}$ & Year & $\begin{array}{c}\text { (\%) Modeled } \\
\text { ILO } \\
\text { Estimation } \\
\end{array}$ & $\begin{array}{c}\text { Net Annual Percentage } \\
\text { Change }(\%)\end{array}$ \\
\hline 1 & 2000 & 57 & 0.00 \\
\hline 2 & 2001 & 57 & 0.00 \\
\hline 3 & 2002 & 57 & 0.00 \\
\hline 4 & 2003 & 58 & 1.00 \\
\hline 5 & 2004 & 58 & 0.00 \\
\hline 6 & 2005 & 58 & 0.00 \\
\hline 7 & 2006 & 57 & -1.00 \\
\hline 8 & 2007 & 56 & -1.00 \\
\hline 9 & 2008 & 55 & -1.00 \\
\hline 10 & 2009 & 54 & -1.00 \\
\hline 11 & 2010 & 54 & 0.00 \\
\hline 12 & 2011 & 53 & -1.00 \\
\hline 13 & 2012 & 52 & -1.00 \\
\hline 14 & 2013 & 52 & 0.00 \\
\hline 15 & 2014 & 52 & 0.00 \\
\hline 16 & 2015 & 52 & 0.00 \\
\hline \multicolumn{2}{|c|}{ C.G.R } & \multicolumn{2}{|r|}{$-1.00 \%$} \\
\hline \multicolumn{2}{|c|}{ MEAN } & \multicolumn{2}{|r|}{55} \\
\hline \multicolumn{2}{|c|}{ C.V } & \multicolumn{2}{|r|}{$4.00 \%$} \\
\hline
\end{tabular}

Source: International Labour Organization, Key Indicators of the Labour Market database and World development Indicators-last updated: 19/07/2016.

Employment plays a crucial role in providing income and thereby improving human welfare. It is observed that India could provide employment to 55 percent of working population. India failed in generating and providing necessary employment to its people in the economy. More importantly, the rate of growth of employment generation was negative only. The only positive and noteworthy thing is employment provided in India was consistent as indicated by the C.V of 4 percent. Thus India on the ground of employment generation and supply has failed and consequently in improving human wellbeing in the country, lastly resulting in unsuccessful in reaching towards a green economy.

\section{Health Expenditure}

Physical and Mental oriented Labour work efficiency ultimately depend on their body fitness and good health otherwise, labours neither physically fit nor healthy for work. The study of health or expenditure on it is important for accounting the green performance of the respective area.

Table 13: Health Expenditure

\begin{tabular}{cccc}
\hline \multicolumn{3}{c}{ Health Expenditure, Total (Private + Public) } \\
\hline Sl. No. & Year & \% of GDP & $\begin{array}{c}\text { Net Annual Percentage } \\
\text { Change (\%) }\end{array}$ \\
\hline 1 & 2000 & 4.31 & 0.00 \\
2 & 2001 & 4.55 & 0.24 \\
3 & 2002 & 4.45 & -0.10 \\
4 & 2003 & 4.35 & -0.10 \\
5 & 2004 & 4.56 & 0.21 \\
6 & 2005 & 4.31 & -0.25 \\
7 & 2006 & 4.09 & -0.22 \\
8 & 2007 & 3.94 & -0.15 \\
9 & 2008 & 3.99 & 0.05 \\
10 & 2009 & 4.05 & 0.06 \\
11 & 2010 & 3.82 & -0.23 \\
12 & 2011 & 3.83 & 0.01 \\
13 & 2012 & 3.81 & -0.02 \\
14 & 2013 & 3.97 & 0.16 \\
15 & 2014 & 3.72 & -0.25 \\
16 & 2015 & 3.67 & -0.05 \\
\hline \multicolumn{3}{c}{ C.G.R } & \multicolumn{3}{c}{$-1.00 \%$} \\
\hline \multicolumn{2}{c}{ MEAN } & \multicolumn{2}{c}{4.09} \\
\hline
\end{tabular}

Source: World Health Organization National Health Account database- http://apps.who.int/nha/database/DataExplorerRegime. aspx and World development Indicators-last updated: 19/07/2016.

The health condition has a special importance in physical as well as mental fitness of people and thereby human wellbeing and green economy 
as well. But the data results adequately reveal that India did not succeed in improving health conditions of its people, because it incurred only meager health expenditure that stood at 4.09 percent of GDP. More importantly, the growth in health expenditure in India is negative which is against human wellbeing and consequently a green economy. But the noteworthy thing is, India was consistent (C.V 7\%) in incurring health expenditure during the study period. Thus, on health grounds, India failed in improving human wellbeing and consequently a green economy as well.

\section{Per Capita Growth of Household Final Consumption Expenditure}

Table 14: Per Capita Growth of Household Final Consumption Expenditure

\begin{tabular}{cccc}
\hline \multicolumn{3}{c}{ Household Final Consumption Expenditure Per Capita } \\
Growth
\end{tabular}

Source: World Bank national accounts data and OECD National Accounts data files and World development Indicators-last updated: 19/07/2016.

Consumption expenditure mainly indicates standard of living, lifestyle of society, tendency for money saving, etc. The level of consumption expenditure by respective country governs the demand and supply of respective goods and services in not only long term period but also short period. Household final consumption expenditure per capita is the market value of all goods and services, including durable products purchased by households (Wikipedia,
2016). It is consumption expenditure that enables satisfaction of wants and thereby human wellbeing. Hence consumption expenditure is an indicator of human wellbeing and thereby a green economy. It is found that the growth in per capita consumption expenditure in India was good (5.37\%), but need for improvement towards better. The only noteworthy thing is per capita consumption expenditure of India grew at the significant rate of 7 percent CGR. But the growth in per capita consumption expenditure was inconsistent as indicated by C.V of 38 percent. Thus on growth in per capita consumption expenditure, India was good but not satisfactory hence necessary for enhancing level of human welfare and attaining green economy.

\section{Life Expectancy at Birth}

The indicator of life expectancy at birth is essential for accounting the real influences of development on human life standard in respective countries. Healthy and Longer life can be obtained through green and sustainable development of around the respective area of human society. Long life to citizens of respective country is the best indicator of physical development of a green economy.

Table 15: Life Expectancy at Birth

\begin{tabular}{cccc}
\hline \multicolumn{4}{c}{ Life Expectancy at Birth } \\
\hline S1. No. & Year & $\begin{array}{c}\text { Total Age } \\
\text { (Years) }\end{array}$ & $\begin{array}{c}\text { Annual Percentage } \\
\text { Change (\%) }\end{array}$ \\
\hline 1 & 2000 & 62 & 0.00 \\
2 & 2001 & 63 & 1.61 \\
3 & 2002 & 63 & 0.00 \\
4 & 2003 & 63 & 0.00 \\
5 & 2004 & 64 & 1.58 \\
6 & 2005 & 64 & 0.00 \\
7 & 2006 & 64 & 0.00 \\
8 & 2007 & 65 & 1.56 \\
9 & 2008 & 65 & 0.00 \\
10 & 2009 & 65 & 0.00 \\
11 & 2010 & 66 & 1.53 \\
12 & 2011 & 66 & 0.00 \\
13 & 2012 & 66 & 0.00 \\
14 & 2013 & 66 & 0.00 \\
15 & 2014 & 67 & 1.51 \\
16 & 2015 & 67 & 0.00 \\
\hline \multicolumn{5}{c}{ C.G.R } \\
\hline \multicolumn{5}{c}{ MEAN } \\
\hline
\end{tabular}

Source: Derived from male and female life expectancy at birth from sources such as: (1) United Nations Population Division. World Population Prospects, (2) United Nations Statistical Division. Population and Vital Statistics Report (various years), (3) Census 
CP Kamble

reports and other statistical publications from national statistical offices, (4) Eurostat: Demographic Statistics, (5) Secretariat of the Pacific Community: Statistics and Demography Programme, and (6) U.S. Census Bureau: International Database and World development Indicators-last updated: 19/07/2016.

Life expectancy is the best indicator of human wellbeing which requires the number of things to be availed and provided. It further helps in attaining green economy for a country. The state of life expectancy in India is good, but not better compared to developed as well as some developing countries. The average life expectancy in India is 65 years. Its growth is just meager and insignificant only. But the only noteworthy thing is the growth was consistent so far as life expectancy in India is considered. Thus, there is a chance and space in improving life expectancy useful for enhancing human wellbeing and a green economy for India.

\section{HYPOTHESIS TESTING}

- $\mathbf{H}_{0}$ : India is not rigorous and sincere in achieving a green economy.

- $\mathbf{H}_{\mathbf{a}}$ : India is rigorous and sincere in achieving a green economy.

The researcher has used the one sample (Two tailed) t-test for this hypothesis testing. This test has been applied to each indicator of different principal area of green economy for examining the role of selected parameters in attaining the green economy in India.

We have used one sample t-test to all indicators of three principal areas of the green economy, at 0.05 percent significance level for 15 degrees of freedom (d.f). Above results show that, except nine, eleven and twelve number indicators of forest rents, employment ratio and health expenditure, remaining all have been contributing to achieving green economy objective. When the p-value is less

Table 16: Hypothesis testing results

\begin{tabular}{|c|c|c|c|c|c|c|c|}
\hline \multicolumn{8}{|c|}{ One sample t-test (Two tailed test) at 95 Percent Confidence Interval } \\
\hline \multirow[t]{2}{*}{$\begin{array}{l}\text { Sl. } \\
\text { No. }\end{array}$} & \multirow[t]{2}{*}{ Sub-Hypothesis } & \multirow{2}{*}{$\begin{array}{l}\text { Degrees of } \\
\text { Freedom }\end{array}$} & $\begin{array}{l}\text { T-Calculated } \\
\text { Value }\end{array}$ & $\begin{array}{l}\text { T-Table } \\
\text { Value }\end{array}$ & $\begin{array}{c}\text { P- } \\
\text { Value }\end{array}$ & \multirow{2}{*}{$\begin{array}{c}\text { Mean } \\
\text { Difference }\end{array}$} & \multirow{2}{*}{$\begin{array}{c}\text { Decision } \\
\text { (Accept or Reject) }\end{array}$} \\
\hline & & & \multicolumn{3}{|c|}{ Equal variances assumed } & & \\
\hline \multirow[t]{2}{*}{1} & $\begin{array}{l}\mathrm{H}_{0}-\mathrm{No} \text { significant depletion of } \\
\text { natural resources has taken place in } \\
\text { India }\end{array}$ & \multirow[t]{2}{*}{15} & \multirow[t]{2}{*}{3.378} & \multirow[t]{2}{*}{2.731} & \multirow{2}{*}{$\begin{array}{c}.0041 \\
(\mathrm{P}<0.05)\end{array}$} & \multirow[t]{2}{*}{68438} & $\mathrm{H}_{0}$-Reject \\
\hline & $\begin{array}{l}\mathrm{H}_{\mathrm{a}} \text {-A significant depletion of natural } \\
\text { resources has taken place in India. }\end{array}$ & & & & & & $\mathrm{H}_{\mathrm{a}}$-Accept \\
\hline \multirow[t]{2}{*}{2} & $\begin{array}{l}\mathrm{H}_{0} \text {-There is no improvement } \\
\text { sanitation facilities in India }\end{array}$ & \multirow{2}{*}{15} & \multirow{2}{*}{5.799} & \multirow{2}{*}{2.731} & \multirow{2}{*}{$\begin{array}{l}.000035 \\
(\mathrm{P}<0.05)\end{array}$} & \multirow{2}{*}{6.12500} & $\mathrm{H}_{0}$-Reject \\
\hline & $\begin{array}{l}\mathrm{H}_{\mathrm{a}} \text {-There is improvement sanitation } \\
\text { facilities in India }\end{array}$ & & & & & & $\mathrm{H}_{\mathrm{a}}$-Accept \\
\hline \multirow[t]{2}{*}{3} & $\begin{array}{l}\mathrm{H}_{0} \text {-India has not improved water } \\
\text { source }\end{array}$ & \multirow[t]{2}{*}{15} & \multirow[t]{2}{*}{6.301} & \multirow[t]{2}{*}{2.731} & \multirow{2}{*}{$\begin{array}{l}.000014 \\
(\mathrm{P}<0.05)\end{array}$} & \multirow[t]{2}{*}{7.50000} & $\mathrm{H}_{0}$-Reject \\
\hline & $\mathrm{H}_{2}$-India has improved water source & & & & & & $\mathrm{H}_{\mathrm{a}}$-Accept \\
\hline \multirow[t]{2}{*}{4} & $\begin{array}{l}\mathrm{H}_{0}-\text { No significant } \mathrm{CO}_{2} \text { has been } \\
\text { emitted by India }\end{array}$ & \multirow{2}{*}{15} & \multirow{2}{*}{4.905} & \multirow{2}{*}{2.731} & \multirow{2}{*}{$\begin{array}{c}.00019 \\
(\mathrm{P}<0.05)\end{array}$} & \multirow{2}{*}{463.1250} & $\mathrm{H}_{0}$-Reject \\
\hline & $\begin{array}{l}\mathrm{H}_{\mathrm{a}} \text {-Significantly } \mathrm{CO}_{2} \text { has been } \\
\text { emitted by India }\end{array}$ & & & & & & $\mathrm{H}_{\mathrm{a}}$-Accept \\
\hline \multirow[t]{2}{*}{5} & $\begin{array}{l}\mathrm{H}_{0} \text {-There is no significant } \\
\text { contribution by renewable energy to } \\
\text { green economy in India }\end{array}$ & \multirow{2}{*}{15} & \multirow{2}{*}{4.976} & \multirow{2}{*}{2.731} & \multirow{2}{*}{$\begin{array}{c}.0001 \\
(\mathrm{P}<0.05)\end{array}$} & \multirow{2}{*}{46.8750} & $\mathrm{H}_{0}$-Reject \\
\hline & $\begin{array}{l}\mathrm{H}_{\mathrm{a}} \text {-Renewable energy has } \\
\text { significantly contributed to a green } \\
\text { economy in India. }\end{array}$ & & & & & & $\mathrm{H}_{\mathrm{a}}$-Accept \\
\hline \multirow[t]{2}{*}{6} & $\begin{array}{l}\mathrm{H}_{0} \text {-There is no significant export of } \\
\text { agricultural raw materials from India }\end{array}$ & 15 & 2161 & & .0064 & 32625 & $\mathrm{H}_{0}$-Reject \\
\hline & $\begin{array}{l}\mathrm{H}_{\mathrm{a}} \text {-There is a significant export of } \\
\text { agricultural raw materials from India }\end{array}$ & 15 & 3.161 & 2.731 & $(\mathrm{P}<0.05)$ & .30625 & $\mathrm{H}_{\mathrm{a}}$-Accept \\
\hline
\end{tabular}




\begin{tabular}{|c|c|c|c|c|c|c|c|}
\hline \multirow{2}{*}{7} & $\begin{array}{l}\mathrm{H}_{0} \text {-India has not significantly } \\
\text { consumed to the electric power }\end{array}$ & \multirow{2}{*}{15} & \multirow{2}{*}{5.017} & \multirow{2}{*}{2.731} & \multirow{2}{*}{$\begin{array}{c}.00015 \\
(\mathrm{P}<0.05)\end{array}$} & \multirow{2}{*}{183.4375} & \multirow{2}{*}{$\frac{\mathrm{H}_{0} \text {-Reject }}{\mathrm{H}_{\mathrm{a}} \text {-Accept }}$} \\
\hline & $\begin{array}{l}\mathrm{H}_{\mathrm{a}} \text {-India has significantly consumed } \\
\text { the electric power }\end{array}$ & & & & & & \\
\hline 8 & $\begin{array}{l}\mathrm{H}_{0} \text {-Energy use in India is not efficient } \\
\mathrm{H}_{3} \text {-Energy use is efficient in India }\end{array}$ & 15 & 4.804 & 2.731 & $\begin{array}{c}.00023 \\
(\mathrm{P}<0.05)\end{array}$ & 105.1250 & $\begin{array}{l}\mathrm{H}_{0}-\text { Reject } \\
\mathrm{H}_{\mathrm{a}} \text {-Accept }\end{array}$ \\
\hline \multirow[t]{2}{*}{9} & $\begin{array}{l}\mathrm{H}_{0} \text {-Forest rents collection in India are } \\
\text { not significant }\end{array}$ & \multirow{2}{*}{15} & \multirow{2}{*}{-3.493} & \multirow{2}{*}{2.731} & \multirow{2}{*}{$\begin{array}{c}.003 \\
(\mathrm{P}<0.05)\end{array}$} & \multirow{2}{*}{-.19688} & $\mathrm{H}_{0}$ - Accept \\
\hline & $\begin{array}{l}\mathrm{H}_{\mathrm{a}} \text {-Forest rents in India are } \\
\text { significant }\end{array}$ & & & & & & $\mathrm{H}_{\mathrm{a}}-$ Reject \\
\hline \multirow[t]{2}{*}{10} & $\begin{array}{l}\mathrm{H}_{0} \text {-Total natural resource rents are } \\
\text { not significant in India }\end{array}$ & \multirow{2}{*}{15} & \multirow{2}{*}{4.197} & \multirow{2}{*}{2.731} & \multirow{2}{*}{$\begin{array}{c}.001 \\
(\mathrm{P}<0.05)\end{array}$} & \multirow{2}{*}{1.56375} & $\mathrm{H}_{0}$-Reject \\
\hline & $\begin{array}{l}\mathrm{H}_{\mathrm{a}} \text {-Total natural resource rents are } \\
\text { significant in India }\end{array}$ & & & & & & $\mathrm{H}_{\mathrm{a}}$-Accept \\
\hline \multirow[t]{2}{*}{11} & $\begin{array}{l}\mathrm{H}_{0} \text {-GNI per capita growth is not } \\
\text { significant in India }\end{array}$ & \multirow{2}{*}{15} & \multirow{2}{*}{6.662} & \multirow{2}{*}{2.731} & \multirow{2}{*}{$\begin{array}{c}.00001 \\
(\mathrm{P}<0.05)\end{array}$} & \multirow{2}{*}{3.73500} & $\mathrm{H}_{0}$-Reject \\
\hline & $\begin{array}{l}\mathrm{H}_{\mathrm{a}} \text {-GNI per capita growth is } \\
\text { significant in India }\end{array}$ & & & & & & $\mathrm{H}_{\mathrm{a}}$-Accept \\
\hline \multirow[t]{2}{*}{12} & $\begin{array}{l}\mathrm{H}_{0} \text {-Employment ratio is not } \\
\text { significantly increasing in India }\end{array}$ & \multirow{2}{*}{15} & \multirow{2}{*}{-3.137} & \multirow{2}{*}{2.731} & \multirow{2}{*}{$\begin{array}{c}.007 \\
(\mathrm{P}<0.05)\end{array}$} & \multirow{2}{*}{-1.87500} & $\mathrm{H}_{0}$ - Accept \\
\hline & $\begin{array}{l}\mathrm{H}_{1} \text {-Employment ratio is significantly } \\
\text { increasing in India }\end{array}$ & & & & & & $\mathrm{H}_{\mathrm{a}}-$ Reject \\
\hline \multirow[t]{2}{*}{13} & $\begin{array}{l}\mathrm{H}_{0} \text {-There is no significant } \\
\text { expenditure on health by } \\
\text { government in India }\end{array}$ & 15 & -2.998 & 2.731 & .009 & -.22125 & $\mathrm{H}_{0}$ - Accept \\
\hline & $\begin{array}{l}\mathrm{H}_{1} \text {-There is a significant expenditure } \\
\text { on health by government in India }\end{array}$ & & & & $(P<0.05)$ & & $\mathrm{H}_{\mathrm{a}}-$ Reject \\
\hline 14 & $\begin{array}{l}\mathrm{H}_{0} \text {-Household per capita } \\
\text { consumption growth is not } \\
\text { significant in India }\end{array}$ & 15 & 7084 & 721 & .00001 & 264063 & $\mathrm{H}_{0}$-Reject \\
\hline & $\begin{array}{l}\mathrm{H}_{1} \text {-Household per capita } \\
\text { consumption growth is significant in } \\
\text { India }\end{array}$ & 15 & 7.084 & 2.131 & $(\mathrm{P}<0.05)$ & 3.64063 & $\mathrm{H}_{\mathrm{a}}$-Accept \\
\hline 15 & $\begin{array}{l}\mathrm{H}_{0} \text {-There is no significant } \\
\text { improvement in life expectancy at } \\
\text { birth in India }\end{array}$ & 15 & 7.201 & 2.731 & .00001 & 2.75000 & $\mathrm{H}_{0}$-Reject \\
\hline & $\begin{array}{l}\mathrm{H}_{\mathrm{a}} \text {-There is significant improvement } \\
\text { in life expectancy at birth in India }\end{array}$ & & & & $(P<0.05)$ & & $\mathrm{H}_{\mathrm{a}}$-Accept \\
\hline
\end{tabular}

The results are significant at 0.05 percent significant levels for 15 degrees of freedom.

than 0.05. $(\mathrm{P}<0.05)$; along with came out the result about $t$-value. The calculated values of ' $t$ ' are more than the table values of respective indicators. Then we say that respective indicator is contributing to the green economy. It is found that,out of fifteen sub-null hypotheses, thirteen are rejected and alternatives are accepted due to the less p-value along with higher calculated t-values. On the other hand, eleven and twelve number null hypotheses are accepted due to the greater value of ' $p$ ' with table ' $t$ ' value. In conclusion, except the two indicators of health and employment level, India is performing better in attaining green economy.

\section{MAJOR CONCLUSIONS AND POLICY SUGGESTIONS}

The major conclusions of the present study are;the depletion of natural resources in India was not over or excessive is a move towards a green economy in connection with the indicator of natural resource depletion. The state of sanitation facilities in India is not very much happy and satisfactory. Access to water shows for India it is good, but not better which reveals India has failed in providing drinking water, consequently economic transformation and green economy for India. The discharge of $\mathrm{CO}_{2}$ into atmosphere by India is no doubt grew significantly 
Likewise, per capita $\mathrm{CO}_{2}$ emission of India also grew at considerable rate of 4 percent per annum, with per capita emission of 2.27 tons indicates a signal of danger. The generation as well as supply of energy is dominated by thermal and not by renewable energy. India's export of agricultural raw materials stood at less than two percent of merchandise exports, with growth in agriculture raw material exports considerable which reveals, India did not succeed in efficiently using agriculture as the natural resource and marching towards a green economy. Electricity consumption in India is meager (582 $\mathrm{KWh}$ ) compared to developed countries, but growing at the considerable rate of 5 percent per annum with variations. The growth as well as quantity of energy being consumed in India is meager and hence insignificant only, which reveals India has failed in using energy as resource efficiently and hence attaining of green economy. India could not use forests as natural resource efficiency and thereby to the green economy. India could not do better through GNI per capita growth for promoting wellbeing of the people in the society and consequently green economy for India. India could provide employment to 55 percent of working population, which reveals India's failure in generating and providing necessary employment to its people in the economy. India did not succeed in improving health conditions of its people, because it incurred only meager health expenditure that stood at 4.09 percent of GDP and the growth in health expenditure in India is negative which is against human wellbeing and consequently a green economy. Growth in per capita consumption expenditure in India was good (5.37\%), but need for improvement towards better, which shows India was good but not satisfactory necessary for enhancing level of human welfare and attaining green economy. The state of life expectancy in India is good, but not better compared to developed as well as some developing countries. The average life expectancy in India is 65 years, and growth has been just meager and insignificant only.

The important and policy suggestions of the present study are; planned extensive and intensive efforts are very much necessary from India as well for the development of health, water supply and sanitation facilities. Government of India should be more active and dynamic in realizing their green economy. Participation and involvement of people should be obligatory and enhanced in undertaking various activities useful for attaining the green economy. A separate budget namely green budget or an important part of public budget of India should be prepared and implemented to undertake green economy created activities. India should control carbon emission for environmental protection or sustainability. India should implement the development model based on protection and conservation of renewable natural resources. Government of India should implement innovation awards for local initiatives and participation in sanitation development activities. Government of India should apply the policy of different oil rates (Petrol \& Diesel) for public transportation services and private (Personal) transportation facility. The government should ban on 10 years old two wheeler vehicles, four wheeler and heavy vehicles. Government should provide the green cards like aaddhar card to each person for environmental awareness and earning environmental rewards points. Government should make compulsory the Planting of minimum one tree by one person while getting governmental document. Government should start training and educational programmes in renewable electricity generation technology. The government should open up the government desert barren land for reforestation and cultivation through people initiatives. Government should provide the renewable electricity like solar in rural areas through privatization, wherever possible. Government should generate employment opportunity for the growing younger generation of India in renewable electricity generation and technology. To provide the education and training of forest based occupations to scheduled tribe community and others, levy and collect the excess taxation as penalty and revenue mobilization on non-renewable resources based occupations and industries, adequate provision in budgets for health development, increase ecofriendly electricity generation with emphasis on renewable energy, special agriculture zones like SEZs for agricultural commodities and services exports and increase in consumption expenditure in India through government incentives and control over inequalities are also useful measures. 


\section{REFERENCES}

Articles Factory. 2012. Importance of Electricity-How it Changed People's Lives. Retrieved May 29, 2016, from articlesfactory. com: http:/www.articles factory.com/articles/science/ Importance-of-electricity-how-it-changed-peoples-liv es.html

Bartelmus, P.S. 1999. Green Accounting for a Sustainable Economy Policy Use and Analysis of Environmental Accounts in the Philippines. Journal of Ecological Economics, PII S0921-8009(98): 155-170.

Bluenomics. 2016. Bluenomics. Retrieved May 30, 2016, from Bluenomics: http://www.bluenomics/glossary/coal_rents

Bowen, A. and Fankhauser, S. 2011. The Green Growth Narrative: Paradigm Shift or Just Spin. Global Environmental Change, 21(4): 1157-1159.

Census, I.P. 2011. Population Composition. New Delhi: Government of India.

Dutt, A.K. and Rao, M.J. 1996. Growth, Distribution and the Environment: Sustainable Development in India. Journal of Pergamon., 24(02): 287-305.

Encyclopedia Britannica. 2008. The Financial Crisis of 2008: Year in Review. Retrieved May 31, 2016, from britannica. com: http://www.britannica.com/topic /Financial-Crisisof-2008-The-1484264

FAO. 2005. Forest area statistics. Retrieved May 29, 2016, from Food and Agriculture Organization of the United Nations: http://www.fao.org /forestry/country/32185/en/ind

FAO. 2009. The State of Food and Agriculture. Rome: Food and Agriculture Organization.

FAO. 2016. Economic Rend and Forest Charges. Retrieved May 30, 2016, from Food and Agriculture Organization of the United Nations: http://www.fao.org/ docrep/009/af168e/ af168e03.htm

GIST. 2005. The Value of Timber, Carbon, Fuel Wood and NonTimber Forest Products in India's Forests. New Delhi: The Energy and Resources Institute.

Gundimeda, H., Sanyal, S., Sinha, R. and Sukhdev, P. 2006. The Value of Biodiversity in India's Forests. New Delhi: Green India States Trust, TERI Press.

Hingane, L.S. and Murtya, R.V. 1984. Growth Rates of Carbon Dioxide Emission in India. Archives for Meteorology, Geophysics, and Bioclimatology Series B., 35(3): 257-264.

Imperial. 2016. The Importance of Energy. Retrieved May 28, 2016, from imperialoil.ca: http://www.imperialoil. ca/canada-english/about_what_upstream_energy.aspx

India, G.E. 2016. Green Economy India. Retrieved June 1, 2016, from greeneconoyindia.com: http://www. greeneconomyindia.com/why_green_econom y.htm

Lee, C.H. 1998. Formulation of Resource Depletion Index. Journal of Resources, Conservation and Recycling, pp. 285-298.
Mahapatra, A. and Mitchell, P.C. 1997. Sustainable Development of Non-Timber Forest Product: Implication for Forest Management in India. Journal of Forest Ecology and Management, pp. 15-29.

Naidu, B.S. 1996. Indian Scenario of Renewable Energy for Sustainable Development. Journal of Energy Policy, 24(06): 575-581.

Planning Commission, GOI. 2013. 11 $1^{\text {th }}$ Five Year Plan (2007-12) Inclusive Growth. (N. D. Oxford University Press, Producer) Retrieved May 28, 2016, from Planningcommission.nic.in:http://planningcommission. nic.in/plans/planrel/fiveyr/11th/11_v1/11th_

Srivastava, L. 2006. Climate Protection for Sustainable Development or Sustainable Development for Climate Protection" A Case Study from India. Journal of Global Environmental Change, pp. 120-122.

Srivastava, L. and Rehman, I.H. 2006. Energy for Sustainable Development in India: Linkages and Strategic Direction. Journal of Energy Policy, pp. 643-654.

Torras, M. 1999. Inequality, Resource Depletion and Welfare Accounting: Application to Indonesia and Costa Rica. Journal of Pergamon., 24(7): 191-1202.

UNEP. 2015. BRICS Environment Ministers Discuss Green Economy, Climate Change. Retrieved March 26, 2016, from Chimate Change Policy and Practice: http://climate-l.iisd. org/news/brics-environment-ministers-discuss-greeneconomy -climate-change

UNEP. 2015. United Nations Environmental Programme, MOSCOW. Retrieved March 26, 2016, from unep. org: http://www.unep.org/newscentre/Default.aspx? DocumentID=26811\&Article ID=34980\&l=en; vol.1.pdf

United Nations. 2012. The Millennium Development Goals Report. New York: United Nations.

WERTC. 2012. Sustainable Solid Waste Management in India. Retrieved March 24, 2016, from Waste to Energy Research and Technology Council: http://swmindia.blogspot.in /2012/10/impacts-of-improper-solid-waste.html

WHO \& UNICEF. 2010. Progress on Sanitation and Drinking Water. Switzerland: World Health Organization and UNICEF.

Wikipedia. 2016. Gross national income. Retrieved June 1, 2016, from en.wikipedia.org: https://en.wikipedia.org/wiki/ Gross_national_income

Wikipedia. 2016. List of countries by household final consumption expenditure per capita. Retrieved June 1, 2016, from en.wikipedia.org: https://en.wikipedia .org/wiki/ List_of_countries_by_household_final_consumption_ expenditure_per_capita

Zpeteman, K. 2001. Sustainability of Nations. International Journal of Sustainable Development, 8(2): 93-109. 
